University of Nebraska - Lincoln

DigitalCommons@University of Nebraska - Lincoln

Publications, Agencies and Staff of the U.S.

Department of Commerce

U.S. Department of Commerce

2010

Compromising genetic diversity in the wild: unmonitored large-

scale release of plants and animals

\author{
Linda Laikre \\ Stockholm University, linda.laikre@popgen.su.se \\ Michael K. Schwartz \\ USDA Forest Service, mkschwartz@fs.fed.us \\ Robin Waples \\ NOAA, robin.waples@noaa.gov \\ Nils Ryman \\ Stockholm University, nils.ryman@popgen.su.se \\ GeM Working Group
}

Follow this and additional works at: https://digitalcommons.unl.edu/usdeptcommercepub

Laikre, Linda; Schwartz, Michael K.; Waples, Robin; Ryman, Nils; and GeM Working Group, "Compromising genetic diversity in the wild: unmonitored large-scale release of plants and animals" (2010). Publications, Agencies and Staff of the U.S. Department of Commerce. 483.

https://digitalcommons.unl.edu/usdeptcommercepub/483

This Article is brought to you for free and open access by the U.S. Department of Commerce at DigitalCommons@University of Nebraska - Lincoln. It has been accepted for inclusion in Publications, Agencies and Staff of the U.S. Department of Commerce by an authorized administrator of DigitalCommons@University of Nebraska - Lincoln. 


\title{
Compromising genetic diversity in the wild: unmonitored large-scale release of plants and animals
}

\author{
Linda Laikre ${ }^{1}$, Michael K. Schwartz ${ }^{2}$, Robin S. Waples ${ }^{3}$, Nils Ryman ${ }^{1}$ and \\ The GeM Working Group ${ }^{4}$
}

\begin{abstract}
${ }^{1}$ Department of Zoology, Division of Population Genetics, Stockholm University, S-10691 Stockholm, Sweden
${ }^{2}$ USDA Forest Service, Rocky Mountain Research Station, 800 E. Beckwith Avenue, Missoula, MT 59801, USA

${ }^{3}$ National Marine Fisheries Service, Northwest Fisheries Science Center, Seattle, WA, USA

${ }^{4}$ The NCEAS/NESCent Working Group on Genetic Monitoring (GeM) is chaired by F.W. Allendorf, University of Montana, USA, and M.K. Schwartz, USDA Forest Service, USA. The other members are: C.S. Baker (Oregon State University, USA), D.P. Gregovich (University of Alaska, USA), M.M. Hansen (Aarhus University, Denmark), J.A. Jackson (Oregon State University, USA), K.C. Kendall (Columbia Falls, MT, USA), L. Laikre (Stockholm University, Sweden), K. McKelvey (USDA Forest Service, USA), M.C. Neel (University of Maryland, USA), I. Olivieri (Université de Montpellier II, France), N. Ryman (Stockholm University, Sweden), R. Short Bull (University of Montana, USA), J.B. Stetz (University of Montana, USA), D.A. Tallmon (University of Alaska, USA), C.D. Vojta (US Forest Service, USA), D.M. Waller (University of Wisconsin, USA) and R.S. Waples (National Marine Fisheries Service, USA)
\end{abstract}

Large-scale exploitation of wild animals and plants through fishing, hunting and logging often depends on augmentation through releases of translocated or captively raised individuals. Such releases are performed worldwide in vast numbers. Augmentation can be demographically and economically beneficial but can also cause four types of adverse genetic change to wild populations: (1) loss of genetic variation, (2) loss of adaptations, (3) change of population composition, and (4) change of population structure. While adverse genetic impacts are recognized and documented in fisheries, little effort is devoted to actually monitoring them. In forestry and wildlife management, genetic risks associated with releases are largely neglected. We outline key features of programs to effectively monitor consequences of such releases on natural populations.

\section{Occurrence of large-scale releases}

The continued large-scale exploitation of wild animals and plants through activities such as fishing, hunting, and logging is frequently dependent on extensive releases of translocated, captively bred, or cultivated individuals. The scale of these releases is enormous, especially within the fields of forestry, fisheries, and wildlife management [1-3]. Each year worldwide, billions of individuals are translocated and released into settings, where wild populations 'receive' these massive inflows of alien species, populations, and gene pools. Despite the staggering scale of these releases, their potential effects on native biodiversity are largely neglected in research and policy.

Releases are of four categories: (1) species that do not occur naturally at the release site (alien species), (2) individuals whose DNA has been artificially manipulated (genetically modified organisms; GMOs), (3) non-local populations of a species that occurs naturally at the release

Corresponding author: Laikre, L. (linda.laikre@popgen.su.se). site (genetically exotic populations), or (4) local populations from which captive-bred individuals are derived (so-called supportive breeding; [4]). Typically, research and political attention has focused on effects of Category 1 and 2 releases on native biodiversity, even though in many areas the most extensive releases are Category 3 and 4 . Furthermore, potential effects of all four categories on gene-level biodiversity of native populations are largely ignored.

Potentially harmful effects on aquatic gene pools and the need for monitoring of such effects were pointed out almost three decades ago [5] and have been stressed repeatedly in subsequent scientific literature [6-8]. A similar scientific discussion appears largely absent with respect to commercial releases within forestry and wildlife management (but see Ref. [9]), even though the scale of releases and potential risks to natural populations are comparable to those for aquatic species.

Our primary objectives are to: (i) draw attention to the global extent of mass releases and the urgent need for understanding the consequences for natural ecosystems, (ii) review documented genetic effects of releases, (iii) compare the field of fisheries to forestry and wildlife management with respect to the scale and genetic monitoring of releases, and (iv) recommend actions to address identified concerns. We note a general lack of research and monitoring of genetic and ecological impacts of large-scale releases, even in fisheries where the risks have been widely recognized for so long. After briefly describing Category 1 and 2 releases, we focus on Category 3 because commercial releases of this type are poorly studied, but conducted on a large scale. We also give examples of Category 4 releases in fisheries, where this type of program has become common following recognition of the potential adverse genetic effects of Category 3 releases.

Large-scale releases can have positive demographic consequences in some cases and can provide economic or other societal benefits. In such situations, it is important to 
While the aquaculture and forestry industries have conducted largescale releases for decades, several emerging markets have the potential to rapidly become economically important, leading to a plethora of unmonitored releases. Two such markets are biofuels and carbon sequestration.

\section{Biofuels}

Biofuels are fuels derived from plant materials including seeds, grains and woody debris. In the United States, corn ethanol comprises $99 \%$ of biofuels, amounting to 3.4 billion gallons of ethanol per year [44]. Although corn ethanol is currently the dominant biofuel, a booming industry is searching for more efficient species for production, with perennial rhizomatous grasses leading in potential [45]. Unfortunately, some leading candidates for biofuel production (and thus for large-scale releases outside their native geographic range) have high invasive potential and are known to hybridize with endemic species. For example, cordgrass (Spartina spp.) not only hybridizes with native species but the hybrids have become highly invasive in the United Kingdom and North America [46].

It is critical that any plants used for biofuels are sterile hybrids since non-sterile grasses have been notoriously difficult to eradicate or even control once established [45]. Barney and Ditomaso [47] assessed three leading U.S. biofuel candidates and found that two of the species (switchgrass Panicum vigratum L. and giant reed Arundo donax L.) had high invasive potential in some environments. In contrast, giant reed posed a low risk if sterile. One missing element to the biofuel "food, energy, and environment trilemma" [48] is the impact these biofuels can have on native gene pools.

\section{Carbon sequestration}

Carbon sequestration is a technique used for long-term capture and storage of carbon dioxide and other forms of carbon to mitigate global warming. One popular tool for this technique has been reforestation of degraded or non-performing crop or pasture lands. Large-scale tree-planting efforts occur in the tropics partially for carbon sequestration, and are currently worth billions of US dollars. However, chosen tree species are often exotics (frequently Eucalyptus and Pinus spp.) which have desired traits of fast growth, high yield,

balance potential conservation benefits of releases (demographic or genetic rescue [10]) against potentially detrimental, micro-evolutionary changes to native populations that run counter to international goals of conserving and sustainably using genetic diversity. We emphasize that effective monitoring of these risk-benefit tradeoffs is essential to ensure informed decision making, and we stress the need to develop and evaluate protocols for such conservation genetic monitoring.

\section{Alien species (Category 1)}

Commercial releases commonly use alien species. Eucalypts, comprising over 800 species endemic to Australia and surrounding islands, have been spread widely for timber production [9]. Extensive tropical reforestation and carbon sequestration projects cost millions of dollars and often use exotic plantation species adjacent to natural forests (Box 1). Large-scale commercial releases of exotics are not restricted to agriculture and forestry: in Great Britain, 20-35 million game birds are released annually, over 95\% of which are pheasants (Phasianus colchicus) and red-legged partridge. Both of these are non-native species in Great Britain [11]. As a further example, Chile, a leading salmon producer, bases its aquaculture industry on introduced Atlantic salmon [12].

Alien species are recognized as a major threat to biodiversity worldwide and considerable research and political known site preference and high reproduction [49]. Neither the ecological nor genetic impacts of these approaches have been well studied, nor have genetic monitoring programs been established to watch for impacts on native populations. However, recently there has been growing momentum in the international carbon market to have certification standards that require the consideration of native tree species that have positive biodiversity impacts both on and offsite, and that implement biodiversity monitoring (Figure 1, [50]).

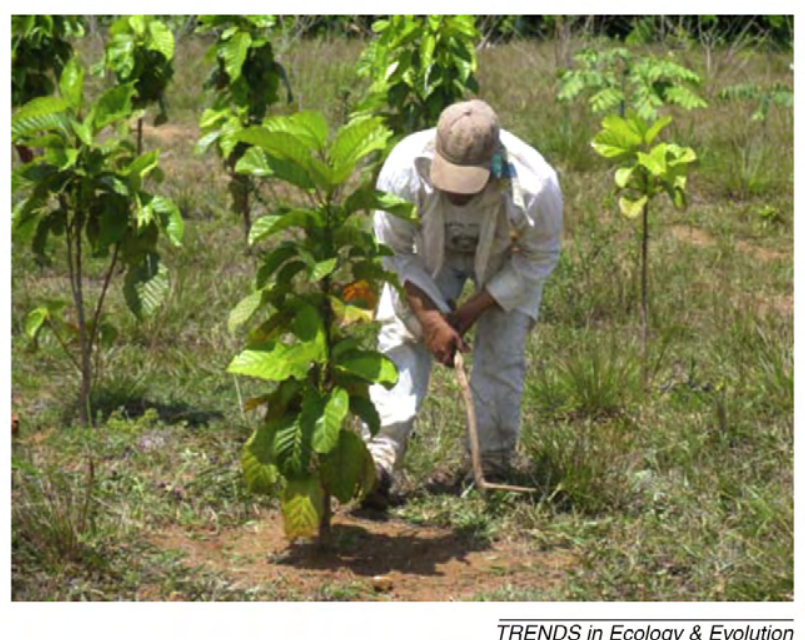

Figure I. A reforestation project in Panama undertaken partially for carbon sequestration purposes, implemented by Futuro Forestal S.A. and ClearSky Climate Solutions, LLC (photo courtesy of Keegan Eisenstadt). Native species are used here (large leaves - Hyeronima alchorneoides, small leaves Swietenia macrophylla), with attention to genetic origin. Where local seed sources remain, individuals are members of the same gene pool as the surrounding naturally occurring populations. Where seed sources have been locally extirpated, they are acquired from other areas within Panama, or in neighboring Costa Rica.

attention has focused on their effects [13]. However, this attention has not stopped widespread use of alien species for commercial purposes, e.g. in agroforestry, causing major problems with invasions of natural and semi-natural ecosystems [14]. Alien species hybridizing with native species represent a particular threat to genetic diversity; introgression of alien gene pools compromises natural genetic variability patterns and can cause outbreeding depression [15].

\section{GMO (Category 2)}

Considerable discussion has focused on methods for assessing and monitoring risks of releasing GMOs into nature [16], especially spread of modified DNA segments into natural populations [17]. Further, as GMOs typically originate from populations that are genetically distinct from native ones near GMO release sites, GMOs also pose risks typical of Category 3 releases (see below). However, these latter risks are rarely discussed in the context of GMOs.

\section{Conspecific populations (Category 3)}

Commercial releases of genetically distinct populations of species that already exist naturally in the release area are conducted on massive scales worldwide, with the species involved including various forest trees and shrubs, game birds and mammals, fish, insects, grasses and other vascular plants (Table 1). In Sweden alone, over 30 billion 
Table 1. Examples of large-scale releases of animals and plants in areas where native populations of the same or closely related species occur.

\begin{tabular}{|c|c|c|c|c|c|c|c|}
\hline Species & $\begin{array}{l}\text { Geographic } \\
\text { region or } \\
\text { locality of } \\
\text { release }\end{array}$ & $\begin{array}{l}\text { Scale and } \\
\text { time frame } \\
\text { of release }\end{array}$ & $\begin{array}{l}\text { Reason } \\
\text { for release }\end{array}$ & $\begin{array}{l}\text { Origin of } \\
\text { released } \\
\text { individuals }\end{array}$ & $\begin{array}{l}\text { Systematic } \\
\text { monitoring } \\
\text { programs of } \\
\text { genetic effects }\end{array}$ & $\begin{array}{l}\text { Studies or } \\
\text { documentation } \\
\text { of effects }\end{array}$ & Source \\
\hline \multicolumn{8}{|l|}{ Fishes } \\
\hline Atlantic salmon (Salmo salar) & $\begin{array}{l}13 \text { Swedish } \\
\text { rivers }\end{array}$ & $\begin{array}{l}\text { Over } 2 \text { million } \\
\text { annually }\end{array}$ & $\begin{array}{l}\text { Commercial } \\
\text { and sports } \\
\text { fishing }\end{array}$ & $\begin{array}{l}\text { Hatchery } \\
\text { populations }\end{array}$ & No & $\begin{array}{l}90 \% \text { of Baltic salmon } \\
\text { of hatchery origin. }\end{array}$ & [18] \\
\hline $\begin{array}{l}\text { Black sea bream } \\
\text { (Acanthopragus schlegelii) }\end{array}$ & $\begin{array}{l}\text { Hiroshima } \\
\text { Bay, Japan }\end{array}$ & $\begin{array}{l}20 \text { million } \\
\text { juveniles } \\
\text { annually }\end{array}$ & $\begin{array}{l}\text { Commercial } \\
\text { fisheries }\end{array}$ & $\begin{array}{l}\text { Hatchery } \\
\text { stocks }\end{array}$ & No & $\begin{array}{l}\text { Reduced number } \\
\text { of alleles in } \\
\text { hatchery fish. }\end{array}$ & [77] \\
\hline Pacific herring (Clupea pallasii) & $\begin{array}{l}\text { Akkeshi Lake } \\
\text { and Bay, Japan }\end{array}$ & $\begin{array}{l}4.3 \text { million during } \\
1987-2005\end{array}$ & $\begin{array}{l}\text { Commercial } \\
\text { fisheries }\end{array}$ & $\begin{array}{l}\text { Hatchery } \\
\text { fish }\end{array}$ & $\begin{array}{l}\text { Yes, to some } \\
\text { extent }\end{array}$ & $\begin{array}{l}\text { Number of rare } \\
\text { alleles decreased. }\end{array}$ & {$[61,78]$} \\
\hline $\begin{array}{l}\text { Pacific salmon species: chum } \\
\text { (Onchorhynchus keta), pink } \\
\text { (O. gorbuscha), masu } \\
\text { (O. masou) }\end{array}$ & $\begin{array}{l}\text { Hokkaido } \\
\text { Island, Japan }\end{array}$ & $\begin{array}{l}1.2 \text { billion } \\
\text { juveniles annually }\end{array}$ & $\begin{array}{l}\text { Commercial } \\
\text { fisheries }\end{array}$ & $\begin{array}{l}\text { Hatchery } \\
\text { fish }\end{array}$ & No & $\begin{array}{l}\text { Dramatic increased } \\
\text { catches of some } \\
\text { species, reduced } \\
\text { catches in others. }\end{array}$ & [79] \\
\hline $\begin{array}{l}\text { Pacific salmon species: chum, } \\
\text { pink, sockeye }(O \text {. nerka), } \\
\text { coho }(O \text {. kisutch) }\end{array}$ & North Pacific & $\begin{array}{l}\text { Around } 4.4 \text { billion } \\
\text { annually }\end{array}$ & $\begin{array}{l}\text { Commercial } \\
\text { and sport } \\
\text { fisheries }\end{array}$ & $\begin{array}{l}\text { Hatchery } \\
\text { fish }\end{array}$ & No & $\begin{array}{l}\text { Replacement of several } \\
\text { wild populations by } \\
\text { hatchery fishes. }\end{array}$ & {$[80]$} \\
\hline Red sea bream (Pagrus major) & $\begin{array}{l}\text { Kagoshima } \\
\text { Bay, Japan }\end{array}$ & $\begin{array}{l}20.8 \text { million } \\
\text { during 1974-2002 }\end{array}$ & $\begin{array}{l}\text { Commercial } \\
\text { fisheries }\end{array}$ & $\begin{array}{l}\text { Hatchery } \\
\text { fish }\end{array}$ & $\begin{array}{l}\text { Yes, genetic } \\
\text { diversity }\end{array}$ & $\begin{array}{l}\text { Reduction of number } \\
\text { of rare alleles. }\end{array}$ & {$[61,81]$} \\
\hline \multicolumn{8}{|l|}{ Birds } \\
\hline Gray partridge (Perdix perdix) & Great Britain & $\begin{array}{l}200000-700000 \\
\text { birds annually }\end{array}$ & Sports hunting & $\begin{array}{l}\text { Captive } \\
\text { bred birds }\end{array}$ & No & No & {$[11]$} \\
\hline \multirow[t]{2}{*}{$\begin{array}{l}\text { Mallard duck } \\
\text { (Anas platyrhynchos) }\end{array}$} & $\begin{array}{l}\text { Southern and } \\
\text { central Sweden }\end{array}$ & $\begin{array}{l}\text { Over } 100000 \\
\text { annually }\end{array}$ & Sports hunting & $\begin{array}{l}\text { Captive stocks, } \\
\text { imported birds }\end{array}$ & No & No & {$[18]$} \\
\hline & France & $\begin{array}{l}\text { Around } 1 \text { million } \\
\text { annually }\end{array}$ & Sports hunting & $\begin{array}{l}\text { Captive stock, } \\
\text { imported birds }\end{array}$ & No & No & {$[82]$} \\
\hline $\begin{array}{l}\text { Red-legged partridge } \\
\text { (Alectoris rufa) }\end{array}$ & Rural Spain & $\begin{array}{l}\text { 3-4 million } \\
\text { birds annually }\end{array}$ & Sports hunting & $\begin{array}{l}\text { Farmed birds } \\
\text { including hybrids }\end{array}$ & No & $\begin{array}{l}\text { Introgression of Alectoris } \\
\text { chukar genes in } 28.7 \% \\
\text { of wild } A \text {. rufa. Hybrids } \\
\text { have lower survival. } \\
\text { Released birds transferred } \\
\text { parasites. }\end{array}$ & {$[25,83,84]$} \\
\hline \multicolumn{8}{|l|}{ Insects } \\
\hline $\begin{array}{l}\text { Bumblebee } \\
\text { (Bombus terrestris) }\end{array}$ & $\begin{array}{l}\text { Southern, } \\
\text { western Europe }\end{array}$ & $\begin{array}{l}\text { Tens of thousands } \\
\text { of colonies }\end{array}$ & $\begin{array}{l}\text { Commercial } \\
\text { pollination }\end{array}$ & $\begin{array}{l}\text { Subspecies } \\
\text { (B. } \text { t. sassaricus) } \\
\text { from Sardinia }\end{array}$ & No & $\begin{array}{l}\text { Genetic differences } \\
\text { between native and } \\
\text { released bees } \\
\text { indicated. }\end{array}$ & {$[85]$} \\
\hline \multicolumn{8}{|l|}{ Forest trees } \\
\hline $\begin{array}{l}\text { Blue gum (Eucalyptus } \\
\text { globulus) }\end{array}$ & $\begin{array}{l}\text { Forest areas } \\
\text { of Australia }\end{array}$ & $\begin{array}{l}70000 \text { ha annually } \\
\text { turned into } \\
\text { plantations of } \\
\text { E. globulus and } \\
\text { non-native } \\
\text { Pinus radiata }\end{array}$ & $\begin{array}{l}\text { Increase } \\
\text { forest } \\
\text { productivity }\end{array}$ & $\begin{array}{l}\text { Selectively bred } \\
\text { non-local } \\
\text { populations }\end{array}$ & No & Yes (Box 3) & {$[24,86,87]$} \\
\hline Norway spruce (Picea abies) & Sweden & $\begin{array}{l}30 \text { billion imported } \\
\text { plants during } \\
20^{\text {th }} \text { century }\end{array}$ & $\begin{array}{l}\text { Increase } \\
\text { forest } \\
\text { productivity }\end{array}$ & $\begin{array}{l}\text { Various parts } \\
\text { of Europe and } \\
\text { Russia }\end{array}$ & No & $\begin{array}{l}\text { No. Central European } \\
\text { spruce have lower } \\
\text { genetic variation } \\
\text { than native spruce. }\end{array}$ & [18] \\
\hline
\end{tabular}


Norway spruce have been imported from various regions in Europe, but documentation is spares and programs to monitor possible effects are nonexistent $[1,18]$. The situation is similar in Norway. During 1960-1980 over 17 million central European Norway spruce were imported and spread in southeastern Østlandet, directly affecting one-third of the local spruce populations. Monitoring efforts have focused exclusively on timber productivity [19], which has an uncertain relationship to long-term fitness in the wild. Furthermore, it is important to evaluate other effects on the genetic composition of native gene pools. Other than in fisheries, little attention has been paid to examining effects of Category 3 releases on biodiversity, although the risks have long been known $[9,15]$.

\section{Local populations: supportive breeding (Category 4)}

Supportive breeding, in which part of a natural population is brought into captivity for reproduction and resulting offspring released into the wild [4], is commonly used in fisheries management, where potential adverse effects are recognized. Category 4 releases minimize risks associated with alien populations but have potentially serious effects on fitness and levels of diversity in native populations [4].

\section{New markets for releases}

We note that several new markets for large-scale releases have emerged recently (Box 1). Also, genetically alien gene pools are widely used for gardening and park management, where commercial mixes of seeds from different populations and species of grasses are spread. For example, 2000 tons of grass seeds and 160 tons of legume seeds of unclear origin were imported to Sweden during 2004-2005 alone to be used for lawns, golf courses, roadsides and pastures.

\section{Genetic effects of releases}

Category 3 releases have four major potential consequences for natural populations: loss of genetic variation, breakdown of adaptations, changes to genetic composition within populations, and breakdown of population structure (genetic differences between populations; Box 2).

Even releases that do not result in gene flow can have genetic consequences if they reduce local population size for example, through competition or disease transmission, or through wasted reproductive effort by native individuals that mate with captively-bred individuals but do not produce viable offspring. The main concern in these cases is that changes to naturally existing genetic diversity within and among populations can reduce viability and productivity of exploited populations. This could be a problem both in the short term by reducing individual fitness and in the long term by reducing the capacity for populations to evolve and adapt to future conditions [20].

Introgression from genetically alien populations has been documented in a number of species subject to large-scale releases (Table 2). Although risks to native

\section{Box 2. Evidence for genetic effects of large-scale releases on fish populations}

Large-scale commercial releases of fishes have been widespread for over a century $[2,15]$. Recently, intensive genetic monitoring programs for aquatic species have documented each of the major effects illustrated in Figure 1.

\section{Among populations}

Genetic structure. Massive releases of coho salmon (Oncorhynchus kisutch) have reduced the level of genetic differentiation between natural populations in Puget Sound, USA [51,52]. In the Central Valley of California, extensive habitat modification and large hatchery programs with release strategies that promote widespread straying have genetically homogenized the metapopulation of fall-run Chinook salmon (Oncorhynchus tshawytscha) [53]. After widespread recruitment failure in 2008, the U.S. imposed the most severe restrictions in history on west coast salmon fisheries. Lindley et al. [53] concluded that a significant contributing factor to the collapse was loss of environmental buffering provided by a diverse array of natural populations.

\section{Within populations}

Genetic composition. Complete replacement of native gene pools of Mediterranean brown trout with introduced populations of Atlantic origin occurs over large areas [54]. Slovenian populations of Adriatic grayling (Thymallus thymallus) have been stocked with Danubian fish for over four decades, and levels of introgression are so high (40-50\%) that few indigenous individuals can be identified [55]. Atlantic salmon (Salmo salar) in the Swedish River Vindelälven, which supports one of the few remaining native populations in the Baltic, are becoming increasingly genetically similar to non-native hatchery stocks [56].

Adaptations. A 37-year study of Atlantic salmon in Ireland [57] found that naturally spawning farmed fish depress wild recruitment and disrupt the capacity of natural populations to adapt to higher water temperatures associated with climate change. Hansen et al. [58] examined Danish populations of brown trout subject to hatchery supplementation for 60 years and found evidence for selection in the wild against alleles associated with non-native hatchery fish. Muhlfeld et al. [59] showed that non-native rainbow trout (Oncorhynchus mykiss) that hybridized with native cutthroat trout (Oncorhynchus clarkii lewisi) in Montana, USA, had high $\mathrm{F}_{1}$ reproductive success. However, in subsequent generations fitness declined by nearly $50 \%$ (compared to fitness of native trout) following $20 \%$ introgression of non-native genes.

Genetic diversity. Unintended introduction of the parasite Gyrodactylus salaris with Atlantic salmon from Sweden used in aquaculture caused the collapse of wild salmon populations in many Norwegian rivers [60], exemplifying loss of diversity not associated with gene flow from introduced populations. Loss of alleles in the natural population following gene flow from commercial releases is reported for red sea bream in Japan [61].

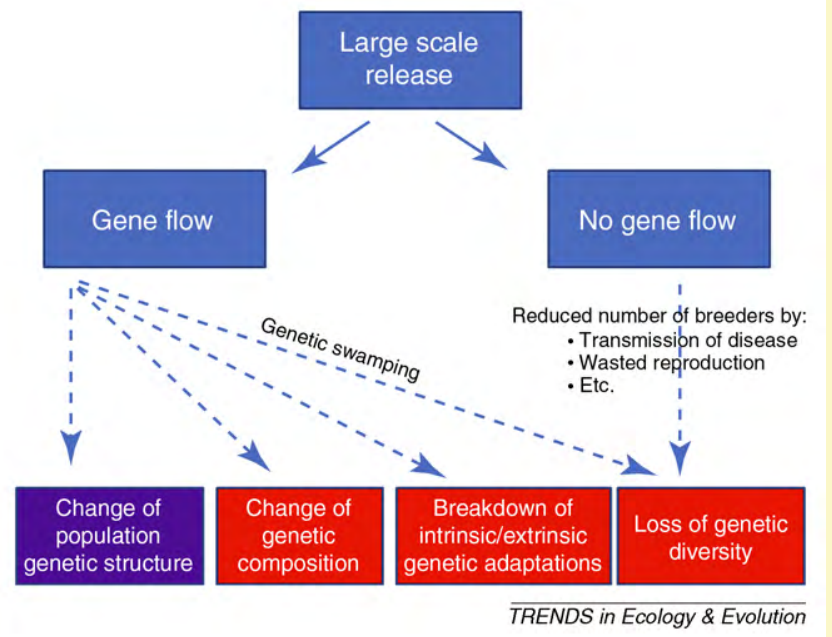

Figure I. Primary pathways by which large-scale releases can change genetic characteristics within (red boxes) and between (purple box) natural populations. 
Table 2. Examples of documented gene flow from genetically alien populations released into native populations

\begin{tabular}{|c|c|c|c|c|c|}
\hline Native species & $\begin{array}{l}\text { Geographic } \\
\text { region or } \\
\text { locality of } \\
\text { release }\end{array}$ & $\begin{array}{l}\text { Species or } \\
\text { population } \\
\text { released }\end{array}$ & $\begin{array}{l}\text { Reason for } \\
\text { release }\end{array}$ & Observation & Sources \\
\hline $\begin{array}{l}\text { Acacia saligna } \\
\text { lindleyi }\end{array}$ & $\begin{array}{l}\text { Southwestern } \\
\text { Australia }\end{array}$ & $\begin{array}{l}\text { Acacia saligna } \\
\text { saligna }\end{array}$ & Agroforestry & $\begin{array}{l}\text { Gene flow rate of } 32 \% \text { from planted } \\
\text { agroforestry into native population. } \\
\text { Small remnant populations of subsp. } \\
\text { lindleyi exposed to high levels of } \\
\text { hybridization. }\end{array}$ & [88] \\
\hline $\begin{array}{l}\text { Black poplar } \\
\text { (Populus nigra L.) }\end{array}$ & Europe & $\begin{array}{l}\text { Black 'lombardy' } \\
\text { poplar (Populus } \\
\text { nigra italica), } \\
\text { hybrids between } \\
\text { P. nigra and } \\
\text { exotic poplar } \\
\text { species. }\end{array}$ & $\begin{array}{l}\text { Ornamental } \\
\text { plantings }\end{array}$ & $\begin{array}{l}\text { Black poplar highly threatened in } \\
\text { western Europe by habitat reductions } \\
\text { and genetic pollution from plantings. } \\
\text { Planted trees represent a narrow } \\
\text { gene pool spread on a wide scale. }\end{array}$ & {$[9,89-91]$} \\
\hline $\begin{array}{l}\text { Brown hare } \\
\text { (Lepus europaeus) }\end{array}$ & Greece & $\begin{array}{l}\text { Captively reared } \\
\text { brown hares } \\
\text { imported from } \\
\text { Italy, Yugoslavia } \\
\text { and Bulgaria }\end{array}$ & $\begin{array}{l}\text { Maintain } \\
\text { hunting } \\
\text { opportunities }\end{array}$ & $\begin{array}{l}\text { Introgression of genes from released } \\
\text { hares into natural populations } \\
\text { detected. }\end{array}$ & [92] \\
\hline $\begin{array}{l}\text { California tiger } \\
\text { salamander } \\
\text { (Ambystoma } \\
\text { californiense) }\end{array}$ & $\begin{array}{l}\text { Gonzales, } \\
\text { Monterey } \\
\text { County, } \\
\text { California, } \\
\text { USA }\end{array}$ & $\begin{array}{l}\text { The congener } \\
\text { tiger salamander } \\
\text { Ambystoma } \\
\text { tigrinum }\end{array}$ & $\begin{array}{l}\text { Production } \\
\text { of fish bait }\end{array}$ & $\begin{array}{l}\text { Native species hybridize with released } \\
\text { congener. Less than } 10 \% \text { remaining } \\
\text { pure, native animals detected in six } \\
\text { pools and ponds studied. }\end{array}$ & [93] \\
\hline $\begin{array}{l}\text { Common quail } \\
\text { (Coturnix coturnix } \\
\text { coturnix) }\end{array}$ & $\begin{array}{l}\text { Spain, } \\
\text { Portugal, } \\
\text { France, } \\
\text { Greece }\end{array}$ & $\begin{array}{l}\text { The subspecies } \\
\text { Japanese quail } \\
\text { (C. } \text { c. japonica) } \\
\text { and hybrids. }\end{array}$ & $\begin{array}{l}\text { Game bird } \\
\text { hunting }\end{array}$ & $\begin{array}{l}\text { Thousands of captive bred quails are } \\
\text { released annually. Hybrids observed } \\
\text { in the wild in France and Portugal. } \\
\text { In Italy and Spain } 9 \% \text { of sampled } \\
\text { wild quails were of hybrid origin. }\end{array}$ & {$[94,95]$} \\
\hline $\begin{array}{l}\text { European wild rabbit } \\
\text { (Oryctolagus cuniculus) }\end{array}$ & Spain & $\begin{array}{l}\text { Mixture of two } \\
\text { evolutionary } \\
\text { distinct lineages } \\
\text { of } O \text {. cuniculus. }\end{array}$ & $\begin{array}{l}\text { Sports hunting } \\
\text { and conservation }\end{array}$ & $\begin{array}{l}\text { Genetically exotic rabbits occur in } \\
\text { nature. }\end{array}$ & {$[96]$} \\
\hline Silver fir (Abies alba) & $\begin{array}{l}\text { Bialowieza, } \\
\text { Poland }\end{array}$ & $\begin{array}{l}\text { Exogenous } \\
\text { A. alba }\end{array}$ & Forestry & $\begin{array}{l}\text { Gene flow from planted exogenous } \\
\text { populations threatens genetic } \\
\text { distinctiveness of small, native relict } \\
\text { population. }\end{array}$ & {$[9,97]$} \\
\hline
\end{tabular}

gene pools have been recognized for a variety of species $[20,21]$, the most intense attention has focused on salmonids such as Pacific salmon, Atlantic salmon and brown trout (Box 2, [3]). In Denmark, these concerns have resulted in a ban of all releases of salmonids originating from anything but the local population (i.e. only Category 4 releases are allowed [22]). However, this is the exception even for salmonids. Surprisingly little monitoring of the effects of mass releases has occurred in forestry and wildlife management, but examples are beginning to accumulate such as Eucalypt populations used in Australian forestry (Box $3[9,23,24])$ and exotic game birds in Southern Europe (Tables 1 and 2).

\section{Loss of genetic variation}

Genetic swamping occurs when there is a strong inflow of genes from alien populations into wild ones, a process that can destroy unique gene pools (Box 2, Tables 1 and 2). Wild populations might also lose genetic variation if their effective population size $\left(N_{e}\right)$ is reduced due to increased mortality caused by parasites or diseases transmitted by released individuals. A classic example refers to the effects of the unintended introduction of the parasite Gyrodactylus salaris (an ectoparasite living on the skin of Atlantic salmon) into Norway with juvenile salmon imported from Sweden in the early $1970 \mathrm{~s}$ (Box 2). Substantial mortality in wild populations following spread of parasites through alien populations has been observed in salmon in Japan [3], red partridge in Spain, and rabbits in France and southern Europe [25,26]. Similarly, lower abundance and survival of wild salmon has been observed in areas with aquaculture compared to areas without such activities [27].

With Category 4 releases, genetic diversity can be lost by reduction of overall (wild plus captive) $N_{e}$. Typically, relatively few parents are brought into captivity for reproduction; these parents often contribute disproportionately large numbers of genes to the next generation, potentially resulting in increased rates of inbreeding and genetic drift in the total population. Reduced genetic variation has been observed in populations of salmonid fishes subject to supportive breeding [28]. Parameters required to predict the effects of supportive breeding include the effective sizes of the captive and wild population segments, their relative contributions to the managed population, and the duration of the support program (Box 4, [4]).

\section{Breakdown of adaptations}

Releases can reduce adaptation by causing loss of extrinsic or intrinsic adaptation. Loss of fitness can occur when alleles that confer local adaptation are replaced by ones that are locally non-adaptive. This extrinsic type of fitness 


\section{Box 3. Genetic contamination of eucalypts in Australia}

Genetic risks from large-scale commercial releases appear to be only marginally recognized in forestry. One exception is the considerable research focused on monitoring genetic pollution from Eucalypt species translocated across Australia to establish commercial plantations $[9,23,24,62]$.

Eucalyptus nitens has been extensively introduced from continental Australia to a Tasmanian forestry expanding from 5000 to 117000 ha during 1980-2000 [63]. Of 29 native Tasmanian eucalypt species, 16 are potentially at risk of hybridization [9], and gene flow from plantations into natural stands has been monitored using morphological techniques. Rates of first generation hybridization $\left(F_{1}\right)$ from $E$. nitens pollen dispersal into native Eucalyptus ovata forests were around $7 \%$ within $100 \mathrm{~m}$ of the plantation, and around $1 \%$ within 0.2 $1.6 \mathrm{~km}$. $F_{1}$ hybrids exhibit reduced height and higher levels of mortality, disease and insect damage. $F_{2}$ hybrids and backcrosses have been produced in the lab but due to the long generation length of these trees will not occur in the wild until 1-2 decades from now [62]. The rare, native Tasmanian species Eucalyptus perriniana is at risk of introgression, perhaps even extinction, from $E$. nitens plantations [24], and is genetically monitored. Similar observations occur in Western Australia where gene flow from an agroforest plantation of non-native Eucalyptus loxophleba lissophloia to en-

loss is frequently observed in the $\mathrm{F}_{1}$ generation (Box 3, [10]). Gene flow from a non-local source population can cause breakup of co-adapted gene complexes, i.e. alleles at multiple loci that work synergistically to increase fitness (intrinsic adaptation). Because this breakup is caused by recombination, loss of adaptation generally occurs only in the $\mathrm{F}_{2}$ generation and beyond and can be much more demic remnant populations of the native subspecies supralaevis was estimated at $40 \%$ within $0.5 \mathrm{~km}$ of the plantation [64].

Spread of non-native genes can result in loss of adaptation to local environments. Wilkinson [65] collected Eucalyptus oblique from several adjacent, but ecologically distinct, native forests in Tasmania and raised them in common environments. He found genetic differences in survival, growth and susceptibility to fungi and browsing, reflecting adaptation to micro-geographic habitat. Thus, large-scale spread of seed from a genetically narrow base across a mosaic of ecological patches can constrain local adaptation.

Genetic composition of plants can affect associated communities of other organisms. Barbour et al. $[66,67]$ examined the effects of genetic variation in Eucalyptus globulus on dependent biodiversity. They studied 160 trees representing eight races in a 15-year-old common garden, and showed that genetic composition of trees affects species occurrence and composition of a number of other groups of organisms including arthropods, fungi, snails and spiders, not only on the living trees but also in the associated litter. For instance, a twofold difference in species richness (from 7 to 14 species) and abundance (from 22 to 55 individuals) was observed when comparing bark litter from different genetic groupings. Thus, introgression of alien gene pools can affect biodiversity at species and ecosystem levels.

difficult to detect than loss of extrinsic adaptation. Empirical examples from wild populations show that both types of adaptation can be lost by gene flow from genetically divergent populations [29]. Fitness effects can be insidious: in some studies, increased $\mathrm{F}_{1}$ fitness due to heterosis has been followed by decreased fitness in $\mathrm{F}_{2}$ or later generations as co-adapted gene complexes are eroded (Box 2).

\section{Box 4. Genetic monitoring of commercial releases: red drum in southeastern U.S.}

Marine stock enhancement is conducted on a large scale worldwide $[68]$ and is a good example of Category 4 releases, which artificially enhance local populations in captivity and release offspring into the wild $[4,36]$. Large enhancement efforts have been conducted for over two decades for red drum (Sciaenops ocellatus) in both the Gulf of Mexico and the Atlantic. As many as 25-30 million fingerlings are released each year in Texas alone [69]. State-of-the art genetic monitoring programs associated with these enhancement efforts have provided key information about effects on natural populations:

- Wild populations exhibit a weak pattern of isolation by distance. Estimated $N_{e}$ for local populations is roughly $10^{2}-10^{3}$ compared to a census size on the order of $10^{6}$ adults [70-72].

- Individual broodstock programs typically use 40-200 adults [71-73], but non-random contributions of different parents leads to relatively low hatchery $N_{e}[69,71,72]$. A detailed study of one Texas hatchery in one year estimated the hatchery $N_{e}$ to be 28-47 [71].

- Hatchery fish had habitat usage similar to wild fish in Florida [74] but not in Texas [69].

- Hatchery releases comprised an estimated $1-12 \%$ of the wild population in Texas and Florida and up to $78 \%$ in South Carolina $[69,73]$.

- In Texas, adults used for broodstock had comparable levels of genetic diversity to wild fish, but released fish had lower genetic diversity [69]. No reductions in levels of genetic diversity were detected in wild populations [70].

Most monitoring efforts provide information about within-population genetic diversity (Figure I in Box 2). If hatchery-reared fish make only modest contributions to the overall population (cf. Florida and Texas studies), effects on wild genetic diversity might also be relatively modest (cf Figure 1). However, a program with 50 or fewer effective parents, that produces a substantial fraction of individuals in the next generation (as estimated for at least one program), could greatly reduce overall $N_{e}$. No before and after data are available, so only weak inferences can be made about reductions in population structure Furthermore, no studies have evaluated effects on wild population fitness. This is an important information gap; adaptation to captivity has been demonstrated for a wide variety of taxa [75], and studies for red drum have found moderately high heritabilities for traits that likely would respond to selection in captivity [76].

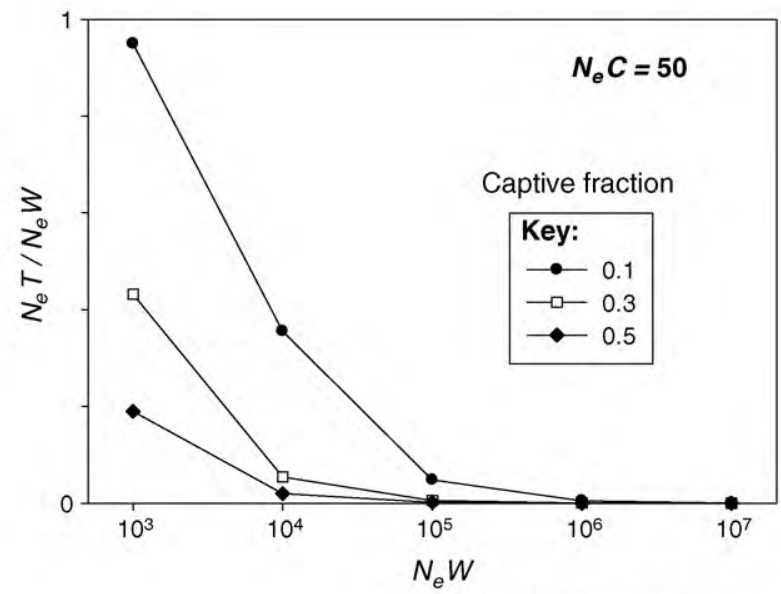

TRENDS in Ecology \& Evolution

Figure I. Overall effective size $\left(N_{e} T\right)$ of a captive-wild system compared to the unsupplemented wild effective size $\left(N_{e} W\right.$. Supportive breeding can severely reduce the $\mathrm{NeT} / N_{e} W$ ratio unless 1) $N_{e} W$ is already low, or 2) captive-bred individuals contribute only a small fraction of genes to the next generation (captive fraction $<$ about 0.1 ). This example assumes that captive effective size $\left(N_{e} C\right)$ is 50 , which is at least as high as values that have been estimated for red drum. 


\section{Change of genetic composition}

Releases can result in a change of the genetic make-up of individual populations if alien alleles establish as a result of gene flow. Several examples exist of natural gene pools being replaced by those of released populations (Boxes 1-3, and Tables 1 and 2). A well-known example involves release of sheepshead minnows (Cyprinodon variegatus) as baitfish in the Pecos River in Texas, with subsequent massive introgression into native Pecos pupfish (Cyprinodon pecosensis) populations in about half the geographic range of this endemic species [20].

\section{Change of population genetic structure}

Most natural animal and plant species are structured into genetically distinct populations because of restricted gene flow, genetic drift and local adaptation. Since large-scale releases can affect these microevolutionary processes, they can alter genetic structuring of natural populations, but such effects have rarely been monitored (but see Box 2).

\section{Changed genetic attributes affect species and ecosystem diversity}

Genetic changes to native populations can have consequences that extend beyond the affected species. Evidence is accumulating to show that genetic changes to one species can affect other species as well as entire communities and ecosystems [30]. For instance, genetic characteristics of individual plant populations can affect the composition and/or species richness of arthropods (Boxes 2 and 3, [31]), and foraging behavior of beavers (Castor canadensis) is affected by genetic makeup of the Populus species on which they feed [32].

New evidence indicates that high levels of genetic diversity increase resilience of species and ecosystems, and that genotypic diversity can complement the role of species diversity in a species-poor coastal ecosystem, and thus help buffer against extreme climatic events. Genetic variation was positively correlated with recovery of seagrass ecosystems following overgrazing and climatic extremes [33]. Reusch et al. [34] conducted manipulative field experiments and found that increasing genotypic diversity of the cosmopolitan seagrass Zostera marina enhanced biomass production, plant density, and invertebrate faunal abundance, despite near-lethal water temperatures.

The native California common cordgrass (Spartina foliosa) introgressed with non-native genes from smooth cordgrass (Spartina alterniflora, Box 1) produces hybrids with up to 400 times the seed and pollen productivity of native plants. Hybrid populations also show altered distribution patterns: they invade marshes, and change the entire community dynamics of those ecosystems, several of which are subject to conservation efforts [35]. Ecosystem effects of genetic introgression from large-scale releases can be particularly devastating in light of current rapid climate change (Box 2).

\section{Why are lessons so slowly learned?}

If potentially deleterious genetic effects of releases on native gene pools have been recognized for several decades, why are these programs still conducted on such a gigantic scale with (in the vast majority of cases) little or no genetic monitoring? One explanation is that potential benefits of rapidly enhancing populations are so easy to visualize, while appreciation of long-term effects on biodiversity and sustainability require a more nuanced understanding of biology. Large release programs are typically supported by influential stakeholders, and these are historically proven to be extremely resistant to change [2]. In the field of fisheries, steady progress has been facilitated particularly by increasingly strong empirical documentation of all of the potential risks outlined above (Table 1, Boxes 2 and 4), as well as consistent conclusions by several high-level science panels (e.g. [36]) that long-term sustainability depends on conserving a diverse array of natural populations. Despite this, hatchery issues remain controversial and a source of polarization within the fisheries community $[7,8]$.

Although the major genetic concerns identified for fisheries also apply to forestry and game management, those disciplines have been slow to incorporate genetic considerations for natural populations into plans for large-scale releases. This might in part reflect the research traditions of university faculties, which in many countries are strongly related to the goal of increasing forest productivity or hunting opportunities. In Sweden, forestry research managers explicitly state that spread of translocated Norway spruce and Scots pine is necessary to maintain forest production and that monitoring the genetic effects on wild populations is not warranted [37].

\section{Poor implementation of international policy on genetic diversity}

The pervasive lack of genetic monitoring of commercial releases reflects a general neglect of gene-level biodiversity associated with implementation of international conservation policy. The Convention on Biological Diversity (CBD) is the most important international political instrument dealing with biodiversity loss. Guidelines for reducing spread of alien species and populations were adopted in 2002 (COP 6 Decision VI/23; www.cbd.int), stating that effects of spread should be monitored, as should biological diversity in general at the levels of ecosystems, species, and genes.

The CBD affects international and national conservation efforts worldwide and although genetic diversity is clearly included in the convention, practical implementation has failed to recognize this sufficiently [38]. Part of the problem is that genetic variation is largely 'invisible' to the human eye. This diversity cannot be readily observed without advanced molecular techniques, making it difficult to generate an understanding of this level of diversity among non-scientists. Conceptually challenging theoretical concepts (such as effective population size) add to this difficulty.

\section{Goals for monitoring large scale releases}

Genetic monitoring of releases should aim to provide answers to the following key questions. (1) What are the genetic characteristics of the natural population(s) prior to the release? (2) Do releases alter these characteristics? If so, (3) what are the biological consequences?

Ideally, monitoring should include genetic screening and statistical evaluation of (i) native population genetic 
structure and level of diversity prior to releases, (ii) natural rates of genetic change of these parameters, (iii) genetic composition of the population(s) used for release, and (iv) genetic structure and amount of diversity of natural population(s) on repeated occasions during and after the release(s). Such monitoring should be included as a basic part of any program for commercial or other releases. Molecular genetic and statistical techniques are readily available [39], although sampling strategies (e.g. number of populations, individuals and loci) need to be evaluated for individual cases to provide acceptable statistical power.

Assessments of risk-benefit tradeoffs are most effective if conducted prior to release activities. Waples and Drake [3] outline a framework for elements of comprehensive risk-benefit analysis that should be conducted prior to fish stock enhancement programs. Similarly, Barbour et al. $[23,24]$ discuss strategies for assessing risks of pollenmediated gene flow from translocated species and hybrids of Corymbia and Eucalyptus globulus plantations into native populations. These studies show that different risk-benefit assessment protocols are needed for different taxa and should be refined to fit particular species.

For releases that have already been carried out, an idealized monitoring design often cannot be followed. Sometimes, however, archived material can help addressing questions of genetic composition prior to release. Within forestry, so-called provenance trials have been used since the $19^{\text {th }}$ century to identify populations with economically important characteristics. Such traditional tree breeding programs are aimed at examining performance of trees from different geographic localities (provenances) to find the best sources of seed for selective breeding and planting. Geographic source materials for provenance trials are thus known, and existing trial stands can be used to study long-term effects of plantations, such as gene flow into neighboring, native populations [40].

\section{Genomics and monitoring large scale releases}

The field of genomics provides new insights and influences the study of large-scale releases in several ways. First, genomics will reduce bias and increase precision and power in estimates of relatedness, population substructure, genetic distance, hybridization and introgression [41]. Using thousands of single nucleotide polymorphisms (SNPs) will provide more power for studies of micro-evolutionary dynamics. Secondly, genomics will allow identifying and monitoring of genes under selection, enabling more direct assessments of the effects of large-scale releases on fitness and long-term evolutionary potential [42]. Third, genomics can help identify the mechanisms of adaptation. If it is possible to investigate how genomic structure of separate individuals influences how well-suited they are for particular environments, this will allow predictions of their survival and fitness as conditions change. Fourth, genomics will provide more sensitive tools to monitor populations under threat from large-scale releases. Ouborg et al. [42] suggest that it will soon be possible to design microarrays that allow detection of specific gene-expression profiles for monitoring purposes. Sample analysis is becoming faster and less expensive. This means microarrays could be designed to detect presence of gene-expres- sion products that are specific to strays or hybrids from large-scale releases. Finally, genomics will facilitate development of community genetics, allowing us to monitor not only changes in individual species, but how such changes affect diversity of entire communities [43].

\section{Summary and conclusions}

Our review has established that commercial releases of many taxa occur globally on an enormous scale. The genetic risks associated with such releases have been known for several decades but are seldom incorporated into management actions. Recent research provides increasing evidence of deleterious effects, and empirical results increasingly document that genetic composition of one species can affect other species and entire ecosystems. Powerful tools, including both molecular genetic techniques (such as genomics) and statistical methods, exist to facilitate genetic monitoring. Nevertheless, only a tiny fraction of releases are monitored for effects on natural populations.

The lack of monitoring efforts is particularly true for forestry and wildlife management. In fisheries, risks are more widely recognized and monitoring efforts better developed, but still inadequate to protect natural populations. The absence of adequate monitoring also reflects a more general neglect of gene-level biodiversity in national and international conservation policy implementation. The Convention on Biological Diversity (CBD) calls for conserving and monitoring gene-level biodiversity, and acknowledges risks from spread of genetically alien populations, but implementation is mostly non-existent. This extreme disconnection between acknowledged risks and actions is probably due in part to the highly visible potential benefits of large-scale releases and the more nuanced effects on natural populations. Genetic variation is largely invisible to the human eye; there is a need for molecular and statistical conceptualization most non-researchers find difficult to grasp. Further, with few exceptions genetic researchers participate to only a very limited extent in CBD and other policy work.

We stress that there is an urgent need for genetic monitoring of the massive commercial releases within forestry, fisheries and wildlife management. Without adequate monitoring, deleterious effects on native genetic diversity can go unnoticed over huge geographic areas. Monitoring is essential not only for maintenance of biodiversity, but also for social, economic and ecological reasons, given that large-scale releases can have long-term effects on ecosystem function and sustainability of living natural resources.

\section{Acknowledgements}

We thank three anonymous reviewers for valuable comments and suggestions. We also thank John Gold and Michael Tringali for information about red drum. This work was conducted as part of the 'Working Group on Genetic Monitoring: Development of Tools for Conservation and Management' supported by the National Evolutionary Synthesis Center (NSF \#EF-0423641) and the National Center for Ecological Analysis and Synthesis, a Center funded by the U.S. National Science Foundation (NSF \#DEB-0553768), the University of California, Santa Barbara, and the State of California. L.L. and N.R. acknowledge financial support from The Swedish Research Council, The Swedish Research Council for Environment, Agricultural Sciences and 
Spatial Planning (Formas), and the BONUS Baltic Organisations' Network for Funding Science EEIG (the BaltGene research project).

\section{References}

1 Laikre, L. and Ryman, N. (1996) Effects on intraspecific biodiversity from harvesting and enhancing natural populations. Ambio 25, 504509

2 Lichatowich, J.A. (1999) Salmon Without Rivers - A History of the Pacific Salmon Crisis, Island Press

3 Waples, R.S. and Drake, J. (2004) Risk/benefit considerations for marine stock enhancement: a Pacific salmon perspective, In Stock Enhancement and Sea Ranching: Developments, Pitfalls and Opportunities (2nd edn) (Leber, K.M. et al., eds), pp. 260-306, Blackwell

4 Ryman, N. and Laikre, L. (1991) Effects of supportive breeding on the genetically effective population size. Conserv. Biol. 5, 325-329

5 Ryman, N., ed. (1981) Fish Gene Pools. Ecological Bulletins 34. Editorial Service, FRN

6 Hindar, K. et al. (1991) Genetic effects of aquaculture on natural fish populations. Aquaculture 98, 259-261

7 Waples, R.S. (1999) Dispelling some myths about hatcheries. Fisheries 24 (1), $12-21$

8 Naish, K.A. et al. (2008) An evaluation of the effects of conservation and fishery enhancement hatcheries on wild populations of salmon. Adv. Mar. Biol. 53, 61-194

9 Potts, B.M. et al. (2003) Turner Review No. 6. Genetic pollution of native eucalypt gene pools - identifying the risks. Aust. J. Bot. 51, 1-25

10 Tallmon, D.A. et al. (2004) The alluring simplicity and complex reality of genetic rescue. Trends Ecol. Evol. 19, 489-496

11 Canning, P. (2005) The UK Game Bird Industry - A Short Study, Report from the ADAS Environmental Consultancy

12 Gajardo, G. and Laikre, L. (2003) Chilean aquaculture boom is based on exotic salmon resources: a conservation paradox. Conserv. Biol. 17, 1173-1174

13 Pearson, D.E. (2009) Invasive plant architecture alters trophic interactions by changing predator abundance and behavior. Oecologica 159, 549-558

14 de Wit, M.P. et al. (2001) Conflicts of interest in environmental management: estimating the costs and benefits of a tree invasion. Biol. Invas. 3, 167-178

15 Allendorf, F.W. et al. (2001) The problems with hybrids: setting conservation guidelines. Trends Ecol. Evol. 16, 613-622

16 DiFazio, S.P. (2004) Gene flow from tree plantations and implications for transgenic risk assessment. In Forest Biotechnology for the 21st Century (Walter, C. and Carson, M., eds), pp. 405-422, Trivandrum, Research Signpost

17 Arriaga, L. et al. (2006) Assessing the risk of releasing transgenic Cucurbita spp. in Mexico. Agr. Ecosys. Environ. 112, 291-299

18 Laikre, L. et al. (2006) Release of alien populations in Sweden. Ambio $35,255-261$

19 Skrøppa, T. et al. (1993) A database for the IUFRO 1964/68 provenance experiment with Norway spruce. In Norway Spruce Provenances and Breeding (Rone, V., ed.), pp. 141-146, Latvian Forestry Research Institute

20 Rhymer, J.M. and Simberloff, D. (1996) Extinction by hybridization and introgression. Annu. Rev. Ecol. Syst. 27, 83-109

21 Hegde, S.G. (2006) The evolution of California's wild radish has resulted in the extinction of its progenitors. Evolution 60, 1187-1197

22 Nielsen, E.E. and Hansen, M.M. (2008) Waking the dead: the valve of population genetic analyses of historical samples. Fish Fish. 9, 450-461

23 Barbour, R.C. et al. (2008) The risk of pollen-mediated gene flow from exotic Corymbia plantations into native Corymbia populations in Australia. Forest Ecol. Manag. 256, 1-19

24 Barbour, R.C. et al. (2008) Assessing the risk of pollen-mediated gene flow from exotic Eucalyptus globulus plantations into native eucalypt populations of Australia. Biol. Conserv. 141, 896-907

25 Villanúa, D. et al. (2008) Sanitary risks of red-legged partridge releases: introduction of parasites. Eur. J. Wildl. Res. 54, 199-204

26 Delibes-Mateos, M. et al. (2008) Rabbit populations and game management: the situation after 15 years of rabbit haemorrhagic disease in central-southern Spain. Biodivers. Conserv. 17, 559-574

27 Ford, J.S. and Myers, R.A. (2008) A global assessment of salmon aquaculture impacts on wild salmonids. PLoS Biol. 6 (e33), DOI: 10.1371/journal.pbio.0060033
28 Hansen, M.M. et al. (2000) Genetic monitoring of supportive breeding in brown trout (Salmo trutta L.), using microsatellite DNA markers. Can. J. Fish. Aquat. Sci 57, 2130-2139

29 Gharrett, A.J. et al. (1999) Outbreeding depression in hybrids between odd- and even-broodyear pink salmon. Aquaculture 173, 117-129

30 Whitham, T.G. et al. (2006) A framework for community and ecosystem genetics: from genes to ecosystems. Nat. Rev. 7, 510-523

31 Crutsinger, G.M. et al. (2006) Plant genotypic diversity predicts community structure and governs an ecosystem process. Science 313, 966-968

32 Bailey, J.K. et al. (2004) Beavers as molecular geneticists: a genetic basis to the foraging of an ecosystem engineer. Ecology 85, 603-608

33 Worm, B. et al. (2006) Impacts of biodiversity loss on ocean ecosystem services. Science $314,787-790$

34 Reusch et al. (2005) Ecosystem recovery after climatic extremes enhanced by genotypic diversity. Proc. Natl. Acad. Sci. U. S. A. 102, 2826-2831

35 Ayres, D.R. et al. (2008) Sexual reproduction of cordgrass hybrids (Spartina foliosa $\mathrm{x}$ alterniflora) invading tidal marshes in San Francisco Bay. Divers. Distrib. 14, 187-195

36 NRC (National Research Council) (2004) Atlantic Salmon in Maine, National Academy Press

37 Lundén, J.-Å. (2007) View of forest managers on spread of alien populations within forestry. In Spread of Genetically Alien Populations in Sweden. What do we know? What do we do? What are the effects? (Report 5683) (Laikre et al. eds), pp. 35-36, Swedish Environmental Protection Agency,.(In Swedish, English summary)

38 Laikre, L. et al. (2010) Neglect of genetic diversity in implementation of the Convention on Biological Diversity. Conserv. Biol. 24, 86-88

39 Schwartz, M.K. et al. (2007) Genetic monitoring as a promising tool for conservation and management. Trends Ecol. Evol. 22, 25-33

40 König, A.O. et al. (2002) Chloroplast DNA variation of oaks in western Central Europe and genetic consequences of human influences. Forest Ecol. Manag. 156, 147-166

41 Avise, J. (2010) Perspective: conservation genetics enters the genomics era. Conserv. Genet. 11, 665-669

42 Ouborg, N.J. et al. (2010) An essay on the necessity and feasibility of conservation genomics. Conserv. Genet. 11, 643-653

$43 \mathrm{Xu}$, J. (2010) Metagenomics and ecosystems biology: conceptual frameworks, tools and methods. In Metagenomics: Theory, Methods, and Applications (Marco, D., ed.), pp. 1-14, Caister Academic Press

44 Farrell, A.E. et al. (2006) Ethanol can contribute to energy and environmental goals. Science $311,506-508$

45 Raghu, S. et al. (2006) Adding biofuels to the invasive species fire? Science 3113,1742

46 Simberloff, D. (2008) Invasion biologists and the biofuels boom: Cassandras or colleagues? Weed Sci. 56, 867-872

47 Barney, J.N. and Ditomaso, J.M. (2008) Nonnative species and bioenergy: are we cultivating the next invader? Bioscience 58, 64-70

48 Tilman, D. et al. (2009) Beneficial biofuels - the food, energy, and environment trilemma. Science 325, 270-271

49 Delagrange, S.C. et al. (2008) Linking multiple-level tree traits with biomass accumulation in native tree species used for reforestation in Panama. Trees 22, 337-349

50 CCBA (2008) Climate, Community \& Biodiversity Project Design Standards Second Edition. The Climate, Community and Biodiversity Alliance (CCBA), Arlington, VA, December, 2008. At: www.climate-standards.org

51 Eldridge, W.H. and Naish, K.A. (2007) Long-term effects of translocation and release numbers on fine-scale population structure among coho salmon (Oncorhynchus kisutch). Mol. Ecol. 16, $2407-2421$

52 Eldridge, W.H. et al. (2009) Long-term changes in the fine-scale population structure of coho salmon populations (Oncorhynchus kisutch) subject to extensive supportive breeding. Heredity 103, 299309

53 Lindley, S.T. et al (2009) What Caused the Sacramento River Fall Chinook Salmon Stock Collapse? National Oceanic and Atmospheric Administration (NOAA) National Marine Fisheries Service Technical Memorandum NOAA-TM-NMFS-SWFSC-447 (Tech Memo NMFSSWFSC 447), NOAA

54 Araguas, R.M. et al. (2009) Role of genetic refuges in the restoration of native gene pools of brown trout. Conserv. Biol. 23, 871-878 
55 Sušnik, S. et al. (2004) Genetic introgression between wild and stocked salmonids and the prospects for using molecular markers in population rehabilitation: the case of the Adriatic grayling (Thymallus thymallus L. 1785). Heredity 93, 273-282

56 Vasemägi, A. et al. (2005) Extensive immigration from compensatory hatchery releases into wild Atlantic salmon population in the Baltic sea: spatio-temporal analysis over 18 years. Heredity 95, 76-83

57 McGinnity, P. et al. (2009) Impact of naturally spawning captive-bred Atlantic salmon on wild populations: depressed recruitment and increased risk of climate-mediated extinction. Proc. Roy. Soc. B 276, 3601-3610

58 Hansen, M.M. et al. (2009) Identifying footprints of selection in stocked brown trout populations: a spatio-temporal approach. Mol. Ecol. 19, $1787-1800$

59 Muhlfeld, C.C. et al. (2009) Hybridization rapidly reduces fitness of a native trout in the wild. Biol. Lett. 5, 328-331

60 Peeler, E. et al. (2006) An assessment of the risk of spreading the fish parasite Gyrodactylus salaris to uninfected territories in the European Union with the movement of live Atlantic salmon (Salmo salar) from coastal waters. Aquaculture 258, 187-197

61 Kitada, S. et al. (2009) Genetic effects of long-term stock enhancement programs. Aquaculture 290, 69-79

62 Barbour, R.C. et al. (2005) Pollen dispersal from exotic eucalypt plantations. Conserv. Genet. 6, 253-257

63 Wood, M.S. et al. (2001) Plantations of Australia-A Report from the National Plantation Inventory and the National Farm Forest Inventory, National Forest Inventory, Bureau of Rural Sciences

64 Sampson, J.F. and Byrne, M. (2008) Outcrossing between an agroforestry plantation and remnant native populations of Eucalyptus loxophleba. Mol. Ecol. 17, 2769-2781

65 Wilkinson, G.R. (2008) Population differentiation within Eucalyptus obliqua: implications for regeneration success and genetic conservation in production forests. Aust. Forest. 71, 4-15

66 Barbour, R.C. et al. (2009) Biodiversity consequences of genetic variation in bark characteristics within a foundation tree species. Conserv. Biol. 23, 1146-1155

67 Barbour, R.C. et al. (2009) A geographic mosaic of genetic variation within a foundation tree species and its community-level consequences. Ecology 90, 1762-1772

68 Leber, K.M. et al., eds (2004) Stock Enhancement and Sea Ranching: Developments, Pitfalls and Opportunities (Second Edition), Blackwell

69 Karlsson, S. et al. (2008) Genetic identification of hatchery-released red drum in Texas bays and estuaries. N. Am. J. Fish. Manage. 28, 12941304

70 Carson, E.W. et al. (2009) Genetic studies of hatchery-supplemented populations of red drum in four Texas bays. N. Am. J. Fish. Manage. 29, $1502-1510$

71 Gold, J.R. et al. (2008) Genetic effective size in populations of hatcheryraised red drum, Sciaenops ocellatus, released for stock enhancement. T. Am. Fish. Soc 137, 1327-1334

72 Tringali, M.D. and Bert, T.M. (1998) Risk to genetic effective size should be an important consideration in fish stock enhancement programs. B. Mar. Sci. 62, 641-659

73 Tringali, M.D. (2006) A Bayesian approach for the genetic tracking of cultured and released individuals. Fish. Res. 77, 159-172

74 Tringali, M.D. et al. (2008) Marine stock enhancement in Florida: A multi-disciplinary, stakeholder-supported, accountability-based approach. Rev. Fish. Sci. 16, 51-57

75 Frankham, R. (2008) Genetic adaptation to captivity in species conservation programs. Mol. Ecol. 17, 325-333

76 Saillant, E. et al. (2007) Heritability of juvenile growth traits in red drum (Sciaenops ocellatus L.). Aquacult. Res. 38, 781-788

77 Blanco Gonzalez, E. and Umino, T. (2009) Fine-scale genetic structure derived from stocking black sea bream, Acanthopagrus schlegelii (Bleeker, 1854), in Hiroshima Bay, Japan. J. Appl. Ichthyol. 25 , $407-410$
78 Suzuki, K., Fukunaga, K. (2004) Recapture rates of released juveniles of Pacific herring in eastern Hokkaido. Tech. Rep. Natl Stock Enhance. Center 2003, Fishery Research Agency, Yokohama, pp. 95-98 (in Japanese).

79 Morita, K. et al. (2006) A review of Pacific salmon hatchery programmes on Hokkaido Island, Japan. ICES J. Mar. Sci. 63, $1353-1363$

80 Zaporozhets, O.M. and Zaporozhets, G.V. (2004) Interaction between hatchery and wild Pacific salmon in the Far East of Russia: A review. Rev. Fish Biol. Fish. 14, 305-319

81 Shishidou, H. and Kitada, S. (2007) Stocking effectiveness of red sea bream Pagrus major in Kagoshima Bay, Japan. Nippon Suisan Gakkaishi 73, 270-277 (in Japanese, English abstract)

82 Mondain-Monval, J.Y. and Girard, O. (2000) Le canard colvert, la sarcelle d'hiver \& autres canards de surface. In Enquête nationale sur les tableaux de chasse à tir. Saison 1998/1999. (Landry, P. and Migot, P., eds) pp. 124-139, Faune Sauvage (In French)

83 Negro, J.J. (2001) RAPD analysis for detection and eradication of hybrid partridges (Alectoris rufa x A. graeca) in Spain. Biol. Conserv. 98, 19-24

84 Villanúa, D. et al. (2007) First occurrence of Eucoleus contortus in a little bustard Tetrax tetrax. A negative effect of red-legged partridge Alectoris rufa releases on steppe bird conservation? Ibis 149, 405406

85 Ings, T.C. (2005) Bumblebees, humble pollinators or assiduous invaders? A population comparison of foraging performance in Bombus terrestris. Oecologia 144, 508-516

86 Parsons, M. and Gavran, M. (2007) Australia's Plantations 2007: Inventory Update. National Plantation Inventory, Bureau of Rural Sciences

87 Davidson, J. et al. (2008) The Changing Face of Australia's Forests, Bureau of Rural Sciences

88 Millar, M.A. and Byrne, M. (2007) Pollen contamination in Acacia saligna: assessing the risks for sustainable agroforestry. Ecosyst. Sustain. Develop. 106, 101-110

89 Cagelli, L. and Lefèvre, F. (1995) The conservation of Populus nigra L. and gene flow with cultivated poplars in Europe. Forest Genet. 2, 135144

90 Vanden Broeck, A. et al. (2005) Natural hybridization between cultivated poplars and their wild relatives: evidence and consequences for native poplar populations. Ann. For. Sci. 62, 601613

91 Smulders, M.J.M. et al. (2008) Natural hybridisation between Populus nigra L. and $P . \mathrm{x}$ canadensis Moench. Hybrid offspring competes for niches along the Rhine River in the Netherlands. Tree Genet. Genom. 4 , $663-675$

92 Mamuris, Z. et al. (2001) Genetic structure of Greek brown hare (Lepus europaeus) populations as revealed by mtDNA RFLP-PCR analysis: implications for conserving genetic diversity. Biol. Conserv. 101, 187196

93 Riley, S.P.D. (2003) Hybridization between a rare, native tiger salamander (Ambystoma californiense) and its introduced congener. Ecol. Appl. 13, 1263-1275

94 Rodríguez-Teijeiro, J.D. et al. (2003) Genetic pollution of Japanese quail on wild common quail populations: a field study. In Proceedings of the XXVIth International Union of Game Biologists Congress and Xth International Perdix Symposium (Vingada, J.V., ed.), Braga. pp. 127

95 Barilani, M. et al. (2005) Detecting hybridization in wild (Coturnix c. coturnix) and domesticated (Coturnix c. japonica) quail populations. Biol. Conserv. 126, 445-455

96 Delibes-Mateos, M. et al. (2008) Translocations as a risk for the conservation of European wild rabbit Oryctolagus cuniculus lineages. Oryx 42, 259-264

97 Mejnartowicz, L. (1996) Cisovka - the relic population of Abies alba and its relationship to man-made silver-fir stands in Bialowieza Primeval Forest. Acta Soc. Bot. Pol. 65, 319-328 (in Polish) 